Article

\title{
Influence of Urban Agglomeration Expansion on Fragmentation of Green Space: A Case Study of Beijing-Tianjin-Hebei Urban Agglomeration
}

\author{
Mingruo Chu ${ }^{1,2}$, Jiayi Lu ${ }^{1,2}$ and Dongqi Sun ${ }^{1, *(D)}$ \\ 1 State Key Laboratory of Regional Sustainable Development Analysis and Simulation, Institute of Geographic \\ Sciences and Natural Resources Research, Chinese Academy of Sciences, Beijing 100101, China; \\ chumingruo0227@igsnrr.ac.cn (M.C.); lujyi.19s@igsnrr.ac.cn (J.L.) \\ 2 University of Chinese Academy of Sciences, Beijing 100049, China \\ * Correspondence: sundq@igsnrr.ac.cn
}

check for updates

Citation: Chu, M.; Lu, J.; Sun, D. Influence of Urban Agglomeration Expansion on Fragmentation of Green Space: A Case Study of Beijing-Tianjin-Hebei Urban Agglomeration. Land 2022, 11, 275. https://doi.org/10.3390/ land 11020275

Academic Editor:

Alexandru-Ionuţ Petrişor

Received: 13 December 2021

Accepted: 7 February 2022

Published: 11 February 2022

Publisher's Note: MDPI stays neutral with regard to jurisdictional claims in published maps and institutional affiliations.

Copyright: (C) 2022 by the authors. Licensee MDPI, Basel, Switzerland. This article is an open access article distributed under the terms and conditions of the Creative Commons Attribution (CC BY) license (https:// creativecommons.org/licenses/by/ $4.0 /)$.

\begin{abstract}
Loss of green space habitats and landscape fragmentation are important reasons for the decline in environmental quality, degradation of ecosystem functions, and decline in biodiversity. Quantifying the spatio-temporal characteristics of landscape fragmentation of green space and its relationship with urban expansion mode is an important basis for improving urban development mode and enhancing urban ecological functions. For this paper, we took the Beijing-Tianjin-Hebei (BTH) urban agglomeration as the research object, a typical rapidly urbanizing area. Through multiscale landscape pattern analysis and statistical analysis, the spatial-temporal evolution characteristics of green space fragmentation in the BTH urban agglomeration from 2000 to 2020 and the influence of urban expansion were analyzed, and the land-use situation in 2030 was predicted by the Future Land Use Simulation (FLUS) model. The main conclusions are as follows: The BTH urban agglomeration has developed rapidly in the last 20 years, showing the characteristics of diffusion and corridor development. The intensity and pattern of urban expansion have significantly affected the pattern of green space, leading to the intensification of domestic green space fragmentation. Among them, urban expansion exerts most severe effects on the fragmentation of farmland, followed by grassland and water. The influence of urban expansion on the scale and fragmentation of forestland is limited. The forecast results in 2030 show that built-up areas may continue to occupy green space. The rate of occupation of farmland will slow down while that of grassland will intensify.
\end{abstract}

Keywords: urban expansion; green space; landscape fragmentation; FLUS model; Beijing-Tianjin-Hebei urban agglomeration

\section{Introduction}

Urban growth is occurring at an unprecedented rate worldwide. The world will reach an urban population rate at $60.4 \%$ by 2030 [1]. As the most direct manifestation of the urbanization process, urban expansion is a powerful sign of progress in social civilizations, a vital result of social and economic development [2]. It poses both opportunities and challenges for the sustainability transition toward long-term balances between human needs and the planet's environmental capacities [3,4]. In China, the "Open Door" Policy initiated in 1978 and the land reform regulation launched in 1987 markedly expedited the urbanization rate [5,6]. Employment opportunities, capital and other factors flooded into cities, further promoting economic development and urban-rural migration [7-10]. The rapid economic development and population growth have contributed to the unprecedented expansion of urban land [11,12]. However, the unsystematic expansion of urban land has given rise to negative environmental problems [13-15] that have become a key issue in global change research [16]. The most prominent manifestation is the fragmentation, degradation and even loss of the pattern of urban green space, which may deprive the living environment, reduce 
biodiversity, and destroy the structure and process of the urban ecosystem [17-19]. Under the background of new urbanization and ecological civilization construction [20], while advancing urban development step by step, we must improve the ecological quality of the city, reduce the negative impact of urban expansion on the ecological environment, and scientifically explore a reasonable way to effectively coordinate the relationship between the demand for built-up areas and green space protection, so as to realize the coordinated development of urban expansion and green space [21].

Since the 20th century, due to the gradual acceleration of urbanization in western countries, the economy has developed rapidly [22]. Scholars began to study the theories and methods of urban land expansion such as scale, mode, and driving forces [23]. The research on urban expansion theory can be traced back to the end of the 19th century. The famous "Central Place Theory" was put forward by the German urban geographer Christaller (1930) and the economist Losch (1940), laying the foundation for the study of urban geography [24]. On this basis, early scholars summarized urban expansion modes from the macroscopic expansion form through a large number of cases, including concentric circle, multi-core, and fan-shaped. Later, new definitions were developed, e.g., edge, corridor, single-core, multi-core and distributed [25], filling, expansion, and enclave [26]; among them, the classification of filling, edge, and enclave is generally accepted, and these models are widely used in the study of urban expansion [27,28]. Afterwards, scholars explored the driving factors of urban expansion and considered that natural factors [29,30], traffic location factors [31], social and economic factors [32], and policy factors [33] were the main driving factors of urban expansion. Since then, similar research results have appeared [34-36]. However, driving factors of urban expansion and their influences vary in different regions and development stages [37].

The research methods for urban land expansion mainly include qualitative analysis and quantitative measurement. Restricted by data and theoretical methods in the early stage, the research framework of urban expansion measurement based on empirical analysis was favored by scholars [11]. In recent years, the emergence of theories and methods such as remote sensing and spatial statistics has made the design and implementation of complex models, analysis, and processing of spatio-temporal data become possible and develop rapidly [38,39], making the combination of remote sensing technology and geographic information system technology the main method of urban expansion research [40]. CA (Cellular Automata) has become one of the most important models for simulating urban expansion [41], and improved models based on CA such as FLUS (Future Land Use Simulation) model [42], multi-agent model [43], SLEUTH model [44], ANN-CA (Artificial Neural Network-Cellular Automata) model [45], and RF-CA-MC (Random Forest-Cellular Automata-Markov Chain) model [46] are often used.

The study of green space began in the 19th century in Britain. Since it plays an important role in protecting the urban ecological environment [47] and influencing urbanization, green space has become a hot research topic and concept in the field of urban space research since the 21st century $[48,49]$. Scholars have carried out research on the concept definition, ecological function and service value, pattern characteristics, and environmental effects of green space [50,51]. Conceptually, green space originated from Howard's "Garden City" theory [52], and after that, it experienced three development stages, i.e., "open space-urban open green space-urban green space" [53]. There is no clear standard for the definition of green space, and it varies for different research purposes [54-56]. Generally speaking, the definition of green space is relatively consistent with the generalized "green space", which refers to natural, semi-natural, and artificial ecosystem networks on all spatial scales in, around, and among urban areas $[57,58]$. For example, some studies summarized the space that provides for ecological service functions, such as parks, forests, green roofs, rivers, and community gardens, as green space [59]; others divided green space into forest land, farmland and parks or forest land, agricultural land, and grassland [60,61]. Combined with research objectives and the actual situation of the research area, in this paper, the definition of green space is "green open space other than built-up areas, includ- 
ing farmland, forests, grassland, and water". The research on its ecological function and service value mainly focuses on protecting urban species' diversity [62], cooling green space [63], purifying the air [64], etc. In terms of pattern characteristics and environmental effects, scholars have carried out a lot of research on the role of green space in human health, economic development, social interaction, and biodiversity [65]. Research shows that the green spatial pattern (patch characteristics, spatial configuration) affects its function and environmental improvement [66-68]. However, there is relatively little research on pattern fragmentation, mainly focusing on the grade of patch area, shape characteristics, and human activities [69]. As for the method of pattern research, it has experienced a gradual transition from qualitative description research to mixed methods of the qualitative and quantitative. In recent years, with the optimization of remote sensing technology and the rapid development of landscape ecology, the quantitative method of landscape pattern metrics has been widely used [69].

To sum it up, the study on the spatial-temporal characteristics and patterns of urban expansion has formed a complete research system. However, on the one hand, in terms of its ecological effects, existing research mostly focuses on the impact of ecosystem services, land carrying capacity, and biodiversity, largely neglecting the impact of green space [70-72]. There is also a lack of analysis on the correlation between urban expansion and the change in green space pattern. On the other hand, the BTH (Beijing-Tianjin-Hebei) urban agglomeration, as one of the important cores of China's economic development, has experienced rapid urbanization and intensive land use changes, bringing about tremendous external pressure on the ecosystem and seriously threatening regional habitat quality. However, few related studies are mostly confined to the inner part of Beijing's urban area, and there may be great differences in landscape changes in urban and urban agglomeration scales, and the research needs to be further expanded. Therefore, to clarify the intensity and situation of the urban expansion of BTH urban agglomeration from 2000 to 2020 as well as the changing trend of green space area and landscape pattern, we used ArcGIS spatial analysis, landscape pattern index, and correlation analysis methods to explore the spatial-temporal evolution characteristics and correlation of urban expansion and green spatial pattern. The specific ideas are as follows: Firstly, we used the data of land use in 2000, 2010, and 2020 to explore the spatial-temporal evolution characteristics of built-up area expansion; secondly, we used spatial analysis and landscape pattern index to explore the spatio-temporal evolution characteristics of green space and its fragmentation degree; thirdly, on this basis, the correlation analysis method was used to analyze the relationship between them, and the FLUS model was used to predict the land use of BTH urban agglomeration in 2030. In this way, we can have an in-depth understanding of the land use of cities in the metropolitan area, which is crucial to the improvement of the green spatial pattern, the sustainable development of urban agglomerations, and the rational overall planning of land resource utilization in the BTH region.

\section{Research Areas and Methods}

\subsection{Study Area}

The study area $\left(113^{\circ} 04^{\prime}-119^{\circ} 53^{\prime} \mathrm{E}, 36^{\circ} 05^{\prime}-42^{\circ} 37^{\prime} \mathrm{N}\right)$ includes Beijing, Tianjin, and Hebei province (Baoding, Langfang, Chengde, Shijiazhuang, Cangzhou, Xingtai, Qinhuangdao, Hengshui, Tangshan, Handan, and Zhangiiakou), which consists of 13 cities (Figure 1). This area covers an area of $218,000 \mathrm{~km}^{2}$ belonging to temperate semi-humid and semi-arid continental monsoon climates. The landform is diverse, mainly plain, and there are also mountains, hills, and basins, with an average elevation of about 200-500 m. Benefiting from topographical conditions, the BTH region is rich in land use types, among which farmland and forestland account for a large proportion. As China's capital economic circle and third economic growth pole, the implementation of BTH's coordinated development strategy in 2014 (one of the current three national strategies) has caused its population to grow rapidly with the population increasing from 90.39 million in 2000 to 110 million in 2020. In addition, the development trend has been rapid, with the GDP rising from 920.71 billion yuan to 
8639.32 billion yuan, and the urbanization rate in core areas of Beijing and Tianjin reaching about $86.6 \%$ and $82.64 \%$, respectively. However, with the acceleration of urban expansion, more and more green spaces have been converted into built-up areas, resulting in regional landscape changes and even destruction, posing challenges to the sustainable development of the BTH region [2,73].

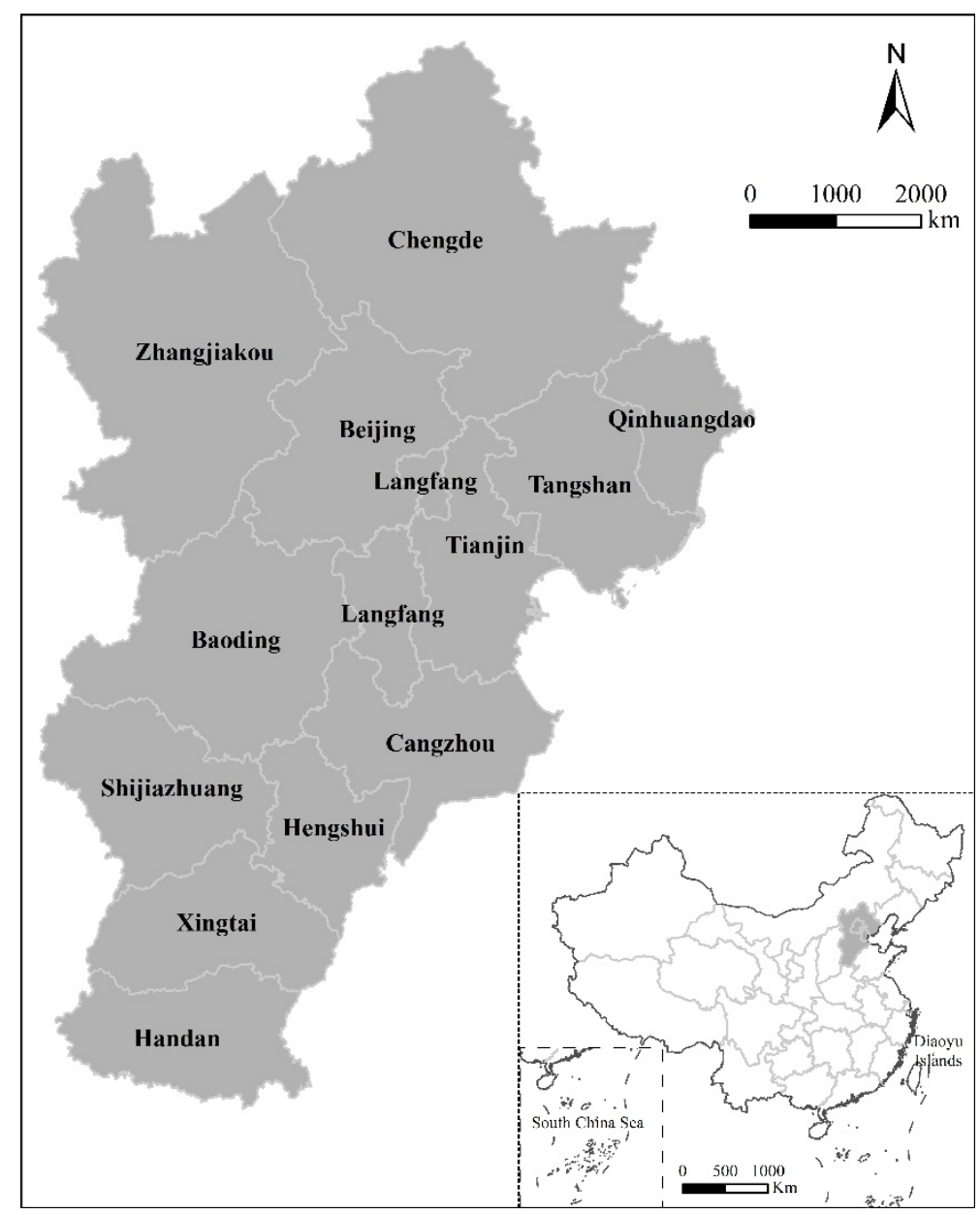

Figure 1. The location of the study area.

\subsection{Data Sources}

Based on the data of land cover in BTH in 2000, 2010, and 2020, and considering the spatial resolution of images and actual situation of land use in the BTH, we divide the land cover into (1) farmland, (2) forestland, (3) grassland, (4) water, (5) built-up areas, and 6) other types. The green space studied in this paper contains farmland, forestland, grassland, and water. The slope and aspect data of the BTH area are obtained from digital elevation model data, and the distances to expressways, main roads, railways, city centers and town centers are calculated using road network data and coordinate data of the town government (Table 1).

\subsection{Methods}

\subsubsection{Land Use Transfer Matrix}

To systematically analyze the change in land use and explore the occupation of green space by built-up areas, we use the land use transfer matrix, which can intuitively indicate 
the direction of increase or decrease in the area for each land use type [74]. The expression is as follows:

$$
S_{i j}=\left[\begin{array}{cccccc}
S_{11} & S_{12} & \ldots & S_{i j} \ldots & S_{1 n} \\
S_{21} & S_{22} & \ldots & S_{2 j} & \ldots & S_{2 n} \\
\ldots & \ldots & \ldots & \ldots & \ldots & \ldots \\
S_{i 1} & S_{i 2} & \ldots & S_{i j} & \ldots & S_{i n} \\
\ldots & \ldots & \ldots & \ldots & \ldots & \ldots \\
S_{n 1} & S_{n 2} & \ldots & S_{n j} & \ldots & S_{n n}
\end{array}\right]
$$

$S_{i j}$ represents transfer area, $i$ represents the land use type at the beginning of the research time, $j$ represents the land use type at the end of the research time, and $n$ represents the quantity of all land use types.

Table 1. Data sources.

\begin{tabular}{cc}
\hline Data & Sources \\
\hline $\begin{array}{c}\text { GlobeLand30 Land Cover Data (2000, 2010, 2020) } \\
\text { DEM data }\end{array}$ & $\begin{array}{c}\text { http://www.globallandcover.com } \\
\text { Road network data }\end{array}$ \\
Administrative division data & $\begin{array}{c}1: 1 \text { million national basic geographic database } \\
\text { https: / planet.openstreetmap.org } \\
\text { (https://www.webmap.cn) }\end{array}$ \\
Coordinate data of the town government & $\begin{array}{c}1: 1 \text { million national basic geographic database } \\
\text { (https://www.webmap.cn) }\end{array}$ \\
\hline
\end{tabular}

\subsubsection{Landscape Metrics}

Landscape metrics is most widely used in landscape pattern analysis. It can highly concentrate the information of landscape pattern and reflect its structural composition and spatial configuration $[69,75,76]$. So it is an effective method to reveal the spatiotemporal change characteristics of the urban green spatial pattern [77]. To analyze the fragmentation characteristics of green space and urban expansion pattern, we chose four typical metrics: Number of Patches (NP), Effective Mesh Size (MESH), Aggregation Index (AI), and Largest Patch Index (LPI), and all the metrics were effective in quantifying spatial patterns [78], the specific explanation are shown in Table 2. In particular, NP is a measure of the number of patches, and to a certain extent, the larger the NP, the more landscape patches, and the greater fragmentation. MESH represents the degree of landscape fragmentation from the area, which combines ecological process, landscape components, and spatial pattern, making it more comprehensive and objective [79]. AI describes the aggregation degree between different patches, and the larger the AI value, the smaller is the landscape fragmentation degree [80]. LPI is used to help understand the fragmentation process; the smaller the LPI value, it means that the landscape is composed of more small patches, and the degree of fragmentation of the landscape increases [81]. We analyzed the spatiotemporal characteristics of green space fragmentation in the BTH urban agglomeration from 2000 to 2020 from landscape level and class level respectively.

Table 2. Interpretation of Landscape Pattern Index.

\begin{tabular}{|c|c|c|}
\hline Indicators & Formulas & Explanations \\
\hline Number of Patches & $N P=n$ & $\begin{array}{c}\text { At the type level, it is equal to the total number of a certain patch } \\
\text { type in the landscape; at the landscape level, it is equal to the total } \\
\text { number of all patches in the landscape. }\end{array}$ \\
\hline Effective Mesh Size & $M E S H=\sum_{j=1}^{n} \mathrm{a}_{i j}^{2} / A \times 100$ & $\begin{array}{c}\text { Describe the landscape fragmentation by dividing the sum of } \\
\text { squares of all patch areas in landscape type } i \text { by the total landscape } \\
\text { area. Unit is } \mathrm{hm}^{2} \text {. }\end{array}$ \\
\hline Aggregation Index & $A I=\left[\sum_{i=1}^{\mathrm{m}}\left(\frac{\mathrm{g}_{i j}}{\max \rightarrow \mathrm{g}_{i j}}\right) \mathrm{P}_{i}\right] \times 100$ & $\begin{array}{c}\text { The number of similar adjacencies of the corresponding type } \\
\text { divided by the maximum value when the type grows from a patch } \\
\text { to the greatest extent. Unit is \%. }\end{array}$ \\
\hline Largest Patch Index & $L P I=\max \left(\mathrm{a}_{i j}\right) / A \times 100$ & $\begin{array}{l}\text { Describe landscape dominance using the proportion of the largest } \\
\text { patch area of landscape type } i \text { to the total landscape area. Unit is } \% \text {. }\end{array}$ \\
\hline
\end{tabular}




\subsubsection{Correlation Analysis Method}

To explore the relationship between green space fragmentation and urban expansion, we adopted the correlation analysis method. The expansion of built-up areas is measured from three dimensions: pattern, quantity, and intensity. They are characterized by the fragmentation pattern of built-up areas (B-MESH), the proportion of built-up areas (BPLAND), and the built-up area expansion intensity index (B-P) [79], respectively. The formula is as follows:

$$
\mathrm{P}=\frac{\mathrm{A}_{\mathrm{t}+\mathrm{n}}-\mathrm{A}_{\mathrm{t}}}{\mathrm{A}} \times \frac{1}{\mathrm{n}} \times 100 \%
$$

$\mathrm{P}$ is the index of urban expansion intensity during the research period, $\mathrm{A}$ is the total area, $A_{t}$ is the area of built-up areas at the initial stage of research, $A_{t+n}$ is the area of built-up areas at the final stage of research, and $n$ is the research period.

$$
\text { PLAND }=\sum_{j=1}^{\mathrm{n}} \mathrm{a}_{i j} / \mathrm{A} \times 100
$$

PLAND (Percentage of Landscape) is a type of landscape pattern metrics. It characterizes the proportion of landscape type $i$ area to the total landscape area, and describes the landscape components, in which $\mathrm{a}_{i j}$ is the area of type $i$ patch $j$; $A$ is the total landscape area; and $\mathrm{n}$ is the number of patches of landscape type $i$. It can describe the proportion of built-up areas quantitively.

The change in green fragmentation is characterized by the effective mesh size of farmland (F1-MESH), forestland (F2-MESH), grassland (G-MESH), and water (W-MESH). Green spatial fragmentation change intensity is characterized by constructing a green spatial fragmentation change intensity index based on MESH, and the calculation formula is as follows:

$$
\mathrm{FG}=\frac{\mathrm{M}_{\mathrm{t}+\mathrm{n}}-\mathrm{M}_{\mathrm{t}}}{\mathrm{A}} \times \frac{1}{\mathrm{n}} \times 1000 \%
$$

FG is the index of green space fragmentation change intensity during the research period, $M_{t}$ is the MESH value of green space at the initial stage of research, and $M_{t+n}$ is the MESH value of green space at the final stage of research.

\subsubsection{FLUS Model}

The FLUS model developed by Liu et al. [42] is the improved cellular automata model for predicting future land use change combining the "top-down" features of the SD model and "bottom-up" features of the cellular automata model; it can better avoid the occurrence of error transmission, and has high simulation accuracy [22]. In this paper, the land use situation of the BTH urban agglomeration in 2030 is predicted by FLUS V2.4 software.

\section{Results and Analysis}

\subsection{Spatial-Temporal Evolution Characteristics of Built-Up Areas}

By analyzing the land use data of the BTH urban agglomeration from 2000 to 2020, we can see that in 2000, the scale of built-up areas was $14,931.96 \mathrm{~km}^{2}$, and by 2010 , it increased to $17,898.76 \mathrm{~km}^{2}$ with an annual growth rate of about $1.99 \%$. From 2010 to 2020 , the urban expansion accelerated, and the area increased by $8630.61 \mathrm{~km}^{2}$ to $26,529.37 \mathrm{~km}^{2}$ with an annual growth rate of $4.82 \%$; the area was 1.78 times that of 2000 . The scale of built-up areas in the study area has been expanding continuously since 2000, and the expansion speed has accelerated in the past decade.

From the perspective of spatial distribution (Figure 2), limited by natural conditions such as topography and development strategy, cities are mainly concentrated in the flat southern plain, which is conducive to population gathering and urban development. The built-up areas are mainly concentrated in the center of each city, and it expands in all directions with the downtown extension. According to the different characteristics of each city, it expands in either the form of a ring, fan, or axis. Specifically, the core functional areas 
in central BTH (Beijing, Tianjin, Baoding, Langfang) are developing rapidly due to their prominent strategic position; driven by the Beijing-Tangshan-Qinhuangdao industrial development zone, it is obvious that the built-up areas of Tangshan and Qinhuangdao are expanding continuously; cities located in the south of urban agglomeration, such as Shijiazhuang, Xingtai, and Handan, are important node cities on the development axis of "Beijing-Baoding-Shijiazhuang", and due to policy support and great development opportunities, they have been expanding at varying degrees in the past 10 years; and for cities located in the north of urban agglomerations like Chengde and Zhangjiakou, which belong to the northwest ecological conservation area, because of their location in mountainous areas and complex terrain, urban expansion mainly takes place along the limited valley space.

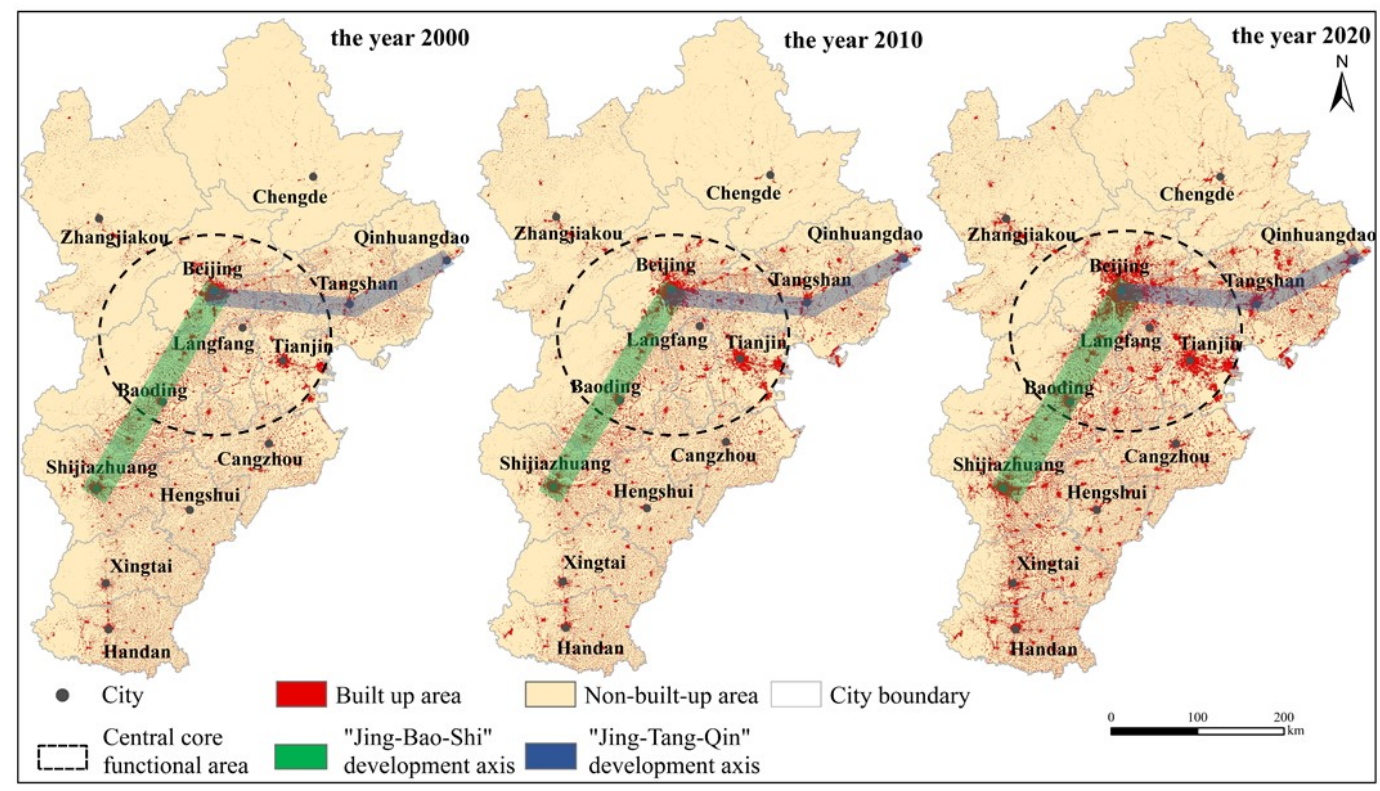

Figure 2. The change of built-up area distribution in the study area from 2000 to 2020.

\subsection{Spatial-Temporal Evolution and Fragmentation Characteristics of Green Space}

\subsubsection{Spatial-Temporal Evolution Characteristics of Green Space}

In terms of green space, the results are shown in Figure 3. In 2000, the total area of green space in BTH city circle was $199,808.23 \mathrm{~km}^{2}$, accounting for $92.49 \%$ of the total area. Among them, farmland was the main part, with an area of $11,6250.78 \mathrm{~km}^{2}$, accounting for $58.19 \%$; forest land was $41,787.48 \mathrm{~km}^{2}$, grassland was $37,781.82 \mathrm{~km}^{2}$, and water was $3964.17 \mathrm{~km}^{2}$, accounting for $20.92 \%, 18.91 \%$, and $1.98 \%$ respectively. The spatial autocorrelation of land indicates that while built-up areas are increasing, other types of land use are decreasing. In 2010, the total area of green space decreased by $1861.66 \mathrm{~km}^{2}$; from 2010 to 2020 , the area of green space rapidly decreased by $9361.74 \mathrm{~km}^{2}$ to $188,584.84 \mathrm{~km}^{2}$, and a total of $13,353.52 \mathrm{~km}^{2}$ of green space was converted into artificial land. Among them, the farmland area dropped significantly from $11,955.65 \mathrm{~km}^{2}$ to $104,295.13 \mathrm{~km}^{2}$. Besides, the grassland scale increased slightly from 2000 to 2010, but it has also decreased in the last 10 years, reaching $38,236.81 \mathrm{~km}^{2}$ in 2020 , with a cumulative decrease of about $454.99 \mathrm{~km}^{2}$. Forestland decreased during the past 10 years, but the overall area increased slightly, with an area of $42,117.68 \mathrm{~km}^{2}$ in 2020 . As for water, due to the limitation of research scale, only $105.13 \mathrm{~km}^{2}$ of water reduction was observed, and the current scale is $3859.04 \mathrm{~km}^{2}$. The proportion of these three land use types in green space remains mainly unchanged. According to the land use transfer matrix (Table 3), we can conclude that the expansion of built-up areas mainly shifted from farmland and grassland, with $11,863.57 \mathrm{~km}^{2}$ and $947.58 \mathrm{~km}^{2}$ respectively, and other land use types also shifted out and transformed into each other to different degrees. 
To sum up, farmland is most affected by urban expansion, followed by grassland. Urban expansion has little impact on forestland and water.

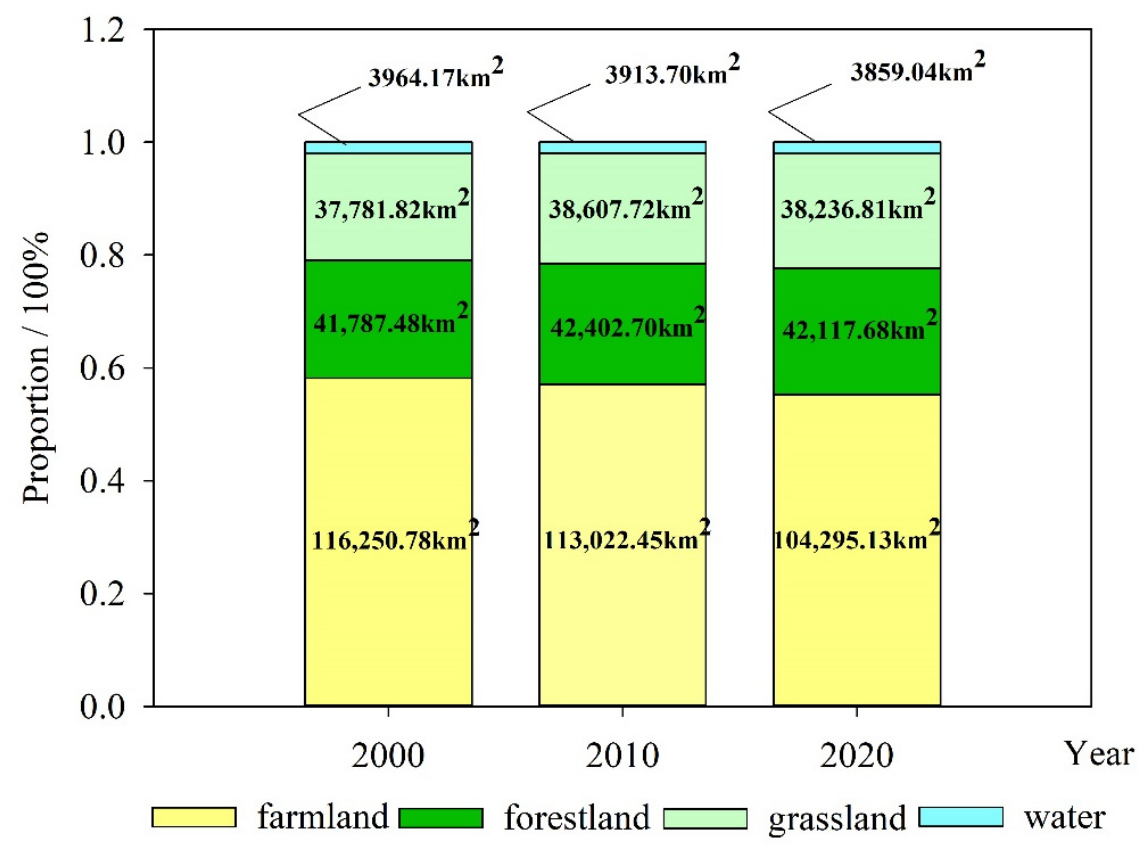

Figure 3. The composition of green space in the study area from 2000 to 2020.

Table 3. Transfer matrix of land use area in the study area $\left(\mathrm{km}^{2}\right)$.

\begin{tabular}{|c|c|c|c|c|c|c|c|c|}
\hline \multirow{2}{*}{\multicolumn{2}{|c|}{ Land Use Types }} & \multicolumn{7}{|c|}{2020} \\
\hline & & Farmland & Forestland & Grassland & Built Up Areas & Water & Other Types & Sum \\
\hline \multirow{7}{*}{2020} & farmland & $97,966.20$ & 1450.50 & 3945.63 & $11,863.57$ & 825.98 & 198.90 & $116,250.78$ \\
\hline & forestland & 751.90 & $34,152.84$ & 6617.71 & 202.59 & 33.90 & 28.54 & $41,787.48$ \\
\hline & grassland & 2756.69 & 6442.92 & $27,338.86$ & 947.58 & 120.06 & 175.71 & $37,781.82$ \\
\hline & built up areas & 1856.39 & 35.47 & 88.62 & $12,878.60$ & 60.86 & 11.67 & $14,931.61$ \\
\hline & water & 876.57 & 31.01 & 165.45 & 339.78 & 2442.29 & 109.07 & 3964.17 \\
\hline & other types & 87.38 & 4.85 & 80.54 & 281.59 & 375.95 & 471.70 & 1302.01 \\
\hline & sum & $104,295.13$ & $42,117.68$ & $38,236.81$ & $26,513.71$ & 3859.04 & 994.99 & \\
\hline
\end{tabular}

Figures 4 and 5 show the distribution of green space and the specific transfer situation in BTH from 2000 to 2020 respectively. From the perspective of spatial distribution (Figure 4), farmland is distributed in the southeastern plain. Built-up areas expand outward continuously, leading to the continuous encroachment of farmland. The overall distribution of forestland in the BTH region is in an "inverted-J" shape, mainly concentrated in the Huairou and Yanqing districts of Beijing and the northeast and southwest of Hebei province. Grassland is mainly distributed around forestland. Because the terrain of forest and grassland distribution area is mainly mountainous, it is relatively less affected by the expansion of urban agglomeration, and the occupation is mainly near the city and the developed areas of Zhangjiakou and Chengde. Large-scale water bodies are mainly distributed along the coast of the Bohai Sea, as well as reservoirs, rivers, and lakes scattered in some cities. Due to the demand for water supply in the BTH region, they are less affected, mainly represented by the erosion of small tributaries.

From the land use transfer matrix (Figure 5), it can be concluded that most areas in the BTH region experienced transfer of land use types in the last 20 years. Specifically, the expansion of built-up areas mainly shifted from farmland and grassland, and mostly in the primitive farmland distributed around cities in the southeast. In addition, farmland was also transferred to grassland, mainly along rivers and lakes in Tianjin and Tangshan, such 
as Chaobai River and Huangtai Lake. The transfer to forestland mainly occurred at the junction of the original forestland and farmland, such as the northern part of Qinhuangdao, Chengde, Zhangjiakou, and the eastern marginal areas of Baoding, Shijiazhuang, Xingtai, and Handan. The transfer to the water was mainly dispersed near the original water body, most obviously among Baodi district of Tianjin, Chaobai River in Ninghe district, Tuanbowa Reservoir in Jinghai district, Caofei Lake in Caofeidian district of Tangshan, and Yuecheng Reservoir in Ci county of Handan. Most of the grasslands were transferred to forestland and farmland, and the transfer to forestland mainly occurred in primitive forestland. The transfer to farmland mainly occurred in Zhangjiakou and Chengde, Yanqing and Pinggu districts of Beijing; Jizhou district of Tianjin; and Fuping county of Baoding. The vicinity of Beitang reservoir in Binhai New Area was an obvious area that was converted into water. Forestland was mainly transformed into grassland and farmland, and the converted grassland was mostly distributed in areas near the primitive forestland. The converted farmland was mainly distributed in Beijing's peripheral administrative areas, Zhangiiakou, Shijiazhuang, and Xingtai, while the converted built-up areas were mostly distributed in Beijing and its surrounding areas. The water was mainly converted into farmland and built-up areas, and the vicinity of the primitive water bodies in Tianjin was transferred to farmland at varying extents. In addition, Caofeidian district in Tangshan, Miyun district in Beijing, and Anxin county in Baoding, all experienced considerable area transfer. The transfer to built-up areas were concentrated in Tianjin, Cangzhou, and Tangshan along the Bohai Sea; Miyun district of Beijing; Zhangbei county and Huailai county of Zhangjiakou; Tang county of Baoding; and Pingshan county of Shijiazhuang. Other types of land use also underwent different degrees of mutual transfer.

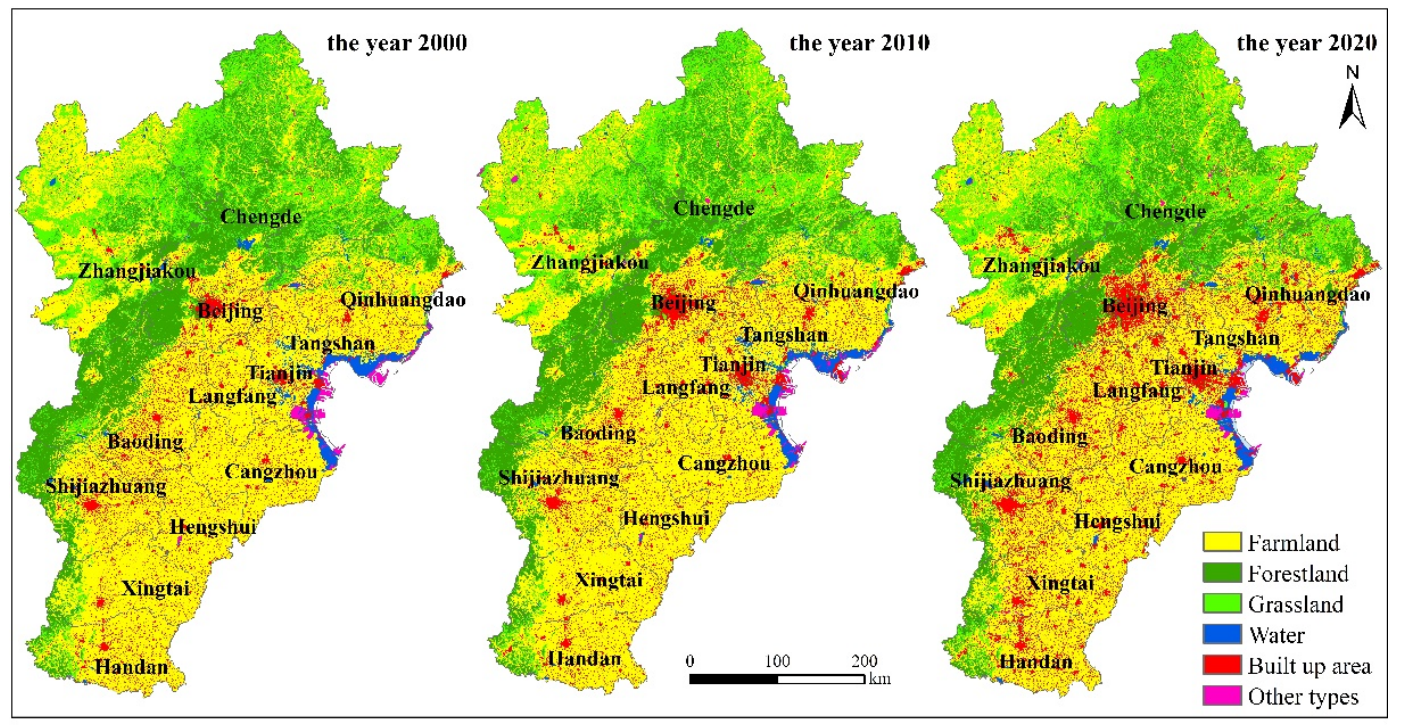

Figure 4. Changes in land use distribution in the study area from 2000 to 2020.

\subsubsection{Fragmentation Characteristics of Green Space}

By analyzing landscape metrics at the landscape level, we can get the overall structural characteristics and spatial distribution of the BTH urban agglomeration, and make an overall study of its landscape evolution characteristics. It can be seen from Table 4 that from 2000 to 2010, NP increased by 11,756, but from 2010 to 2020, it decreased to 331,369. The decrease in MESH and LPI yearly indicates that the landscape patch area tends to break and its shape becomes complicated. The aggregation index indicates the aggregation degree of patches, and the decrease in AI yearly indicates that landscape separation has intensified. Generally speaking, with the interference of human activities, landscape fragmentation in the study area has shown an upward trend over time. 


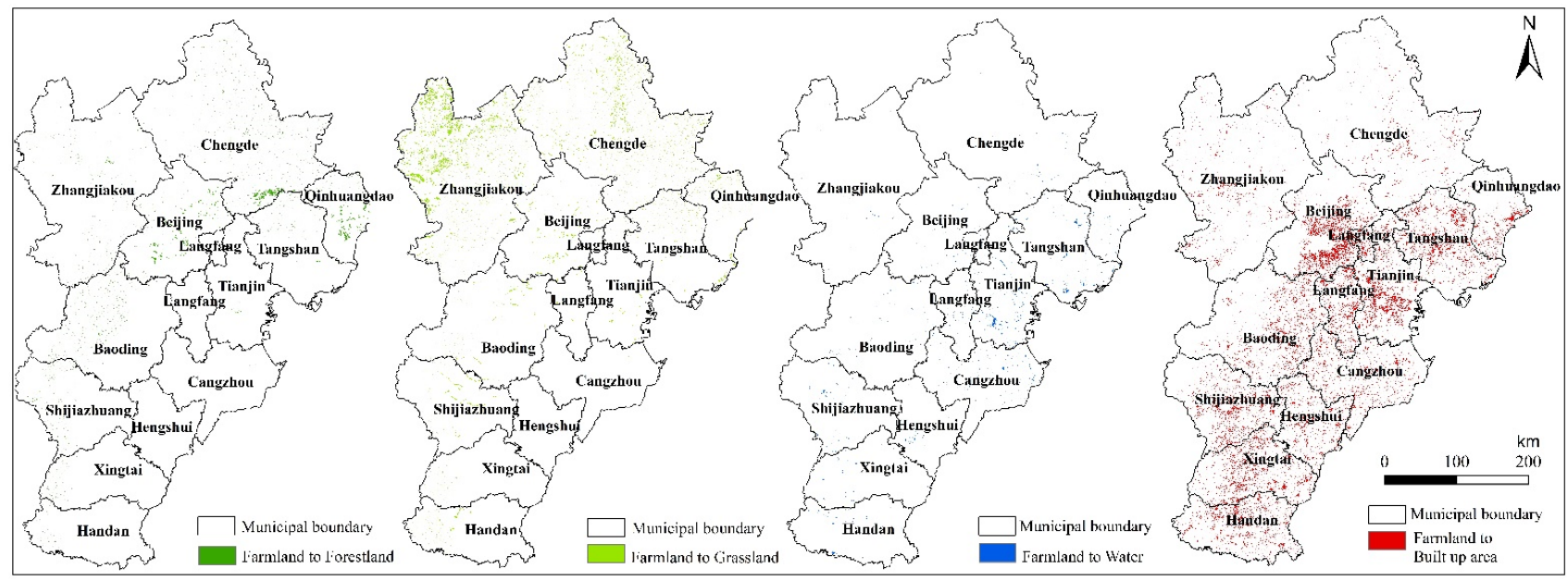

(a)

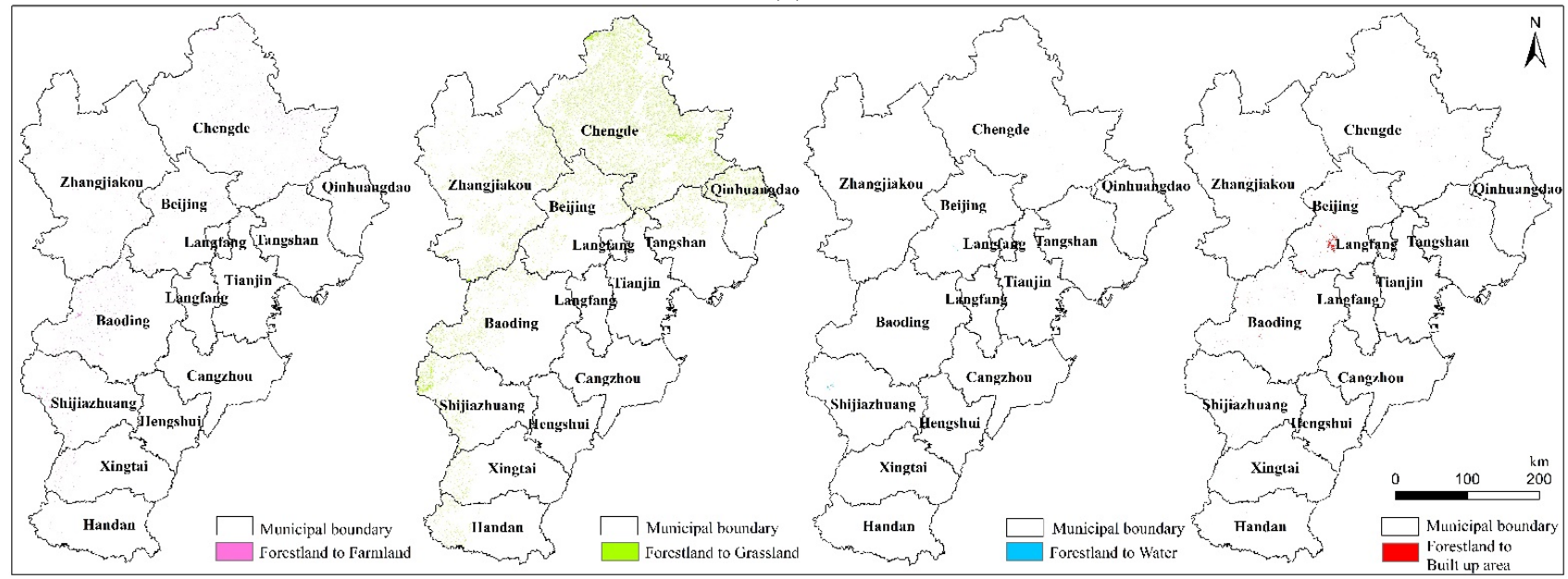

(b)
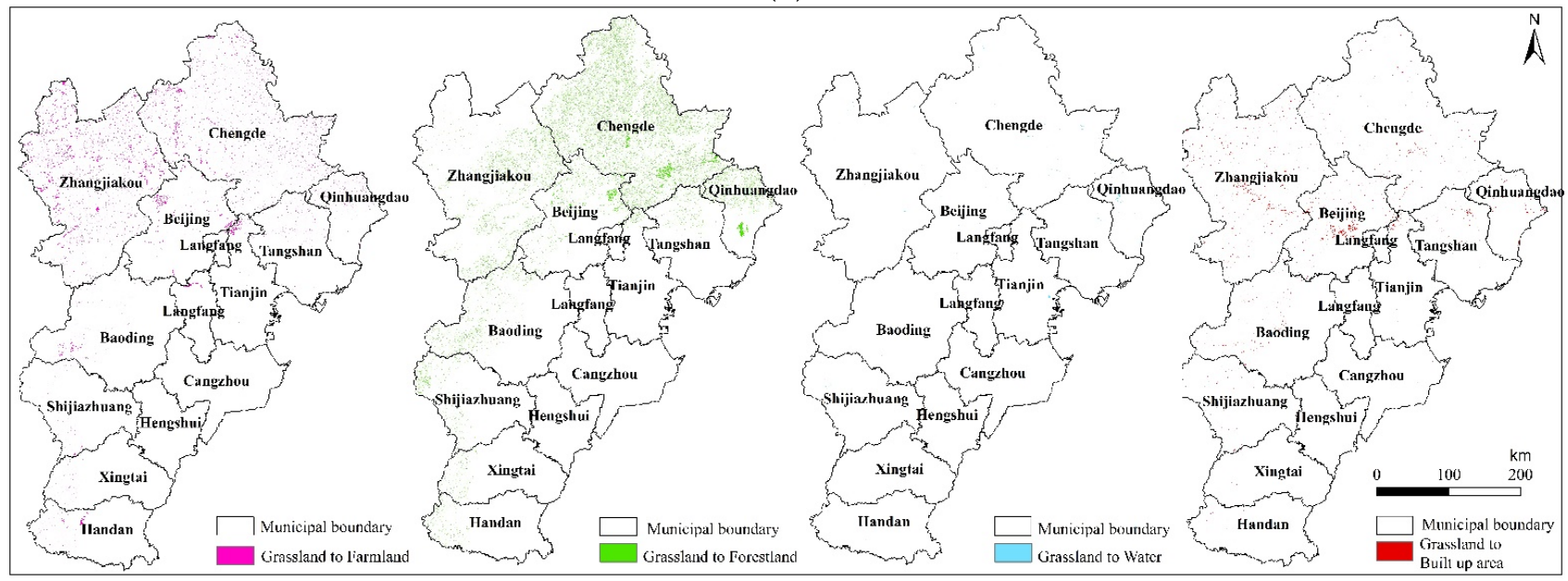

(c)

Figure 5. Cont. 


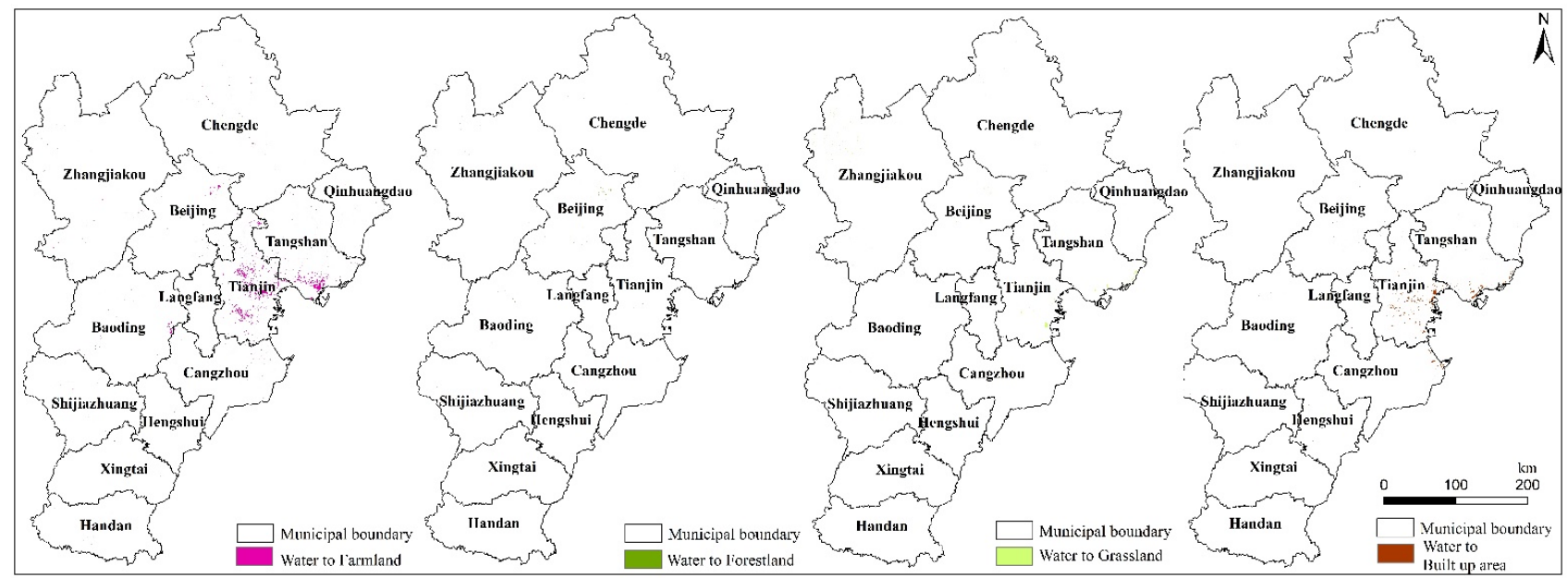

(d)

Figure 5. Land use transfer matrix (a). Land use transfer of farmland in the study area from 2000 to 2020. (b). Land use transfer of forestland in the study area from 2000 to 2020. (c). Land use transfer of grassland in the study area from 2000 to 2020. (d). Land use transfer of water in the study area from 2000 to 2020.

Table 4. The landscape-level metrics in the study area.

\begin{tabular}{cccc}
\hline & $\mathbf{2 0 0 0}$ & $\mathbf{2 0 1 0}$ & $\mathbf{2 0 2 0}$ \\
\hline $\mathrm{NP}$ & 325,191 & 336,947 & 331,369 \\
$\mathrm{MESH} / \mathrm{hm}^{2}$ & $3,929,543.33$ & $3,712,420.49$ & $2,881,932.20$ \\
$\mathrm{AI} / \%$ & 86.16 & 85.72 & 85.12 \\
$\mathrm{LPI} / \%$ & 40.92 & 39.74 & 34.94 \\
\hline
\end{tabular}

Class metrics can represent the structural characteristics and spatial distribution of different landscape types, thus making it possible to analyze a single landscape type. Figure 6 shows the trend of landscape metrics. In terms of NP, farmland, as the main landscape type in the study area, has been continuously increased for 20 years, eventually increasing by about $37 \%$. In addition, its area has continuously decreased by $10.3 \%$, indicating that its scale and integrity have been destroyed. The NP of forestland showed an upward trend in 2000-2010 and a downward trend in 2010-2020, which was consistent with the change in its area. The scale of grassland is not dominant, but the number of patches is always the highest, indicating that the distribution is scattered. Its NP showed a downward trend, while its area showed a trend of first increasing and then decreasing, and the decreasing trend of the number of patches in the last decade was obviously higher than the decreasing rate of the area. To some extent, it showed that the increase in grassland area was mostly based on the expansion of primitive grassland, while its decrease was mostly seen in the disappearance of small patches. However, the water area has been decreasing continuously in the last 20 years, and the number of patches has also decreased, indicating that small tributaries or small patches in water areas have been cut off, dried up, or converted into other land use. The trends of LPI and MESH for different land types are similar. Specifically, the LPI of farmland decreased from $40.92 \%$ to $34.94 \%$, and MESH decreased by $28.1 \%$; LPI and MESH of forestland first increased and then decreased; grassland also increased first and then decreased, and the indexes were lower than those in 2000; LPI and MESH continue to decline in water. In terms of $\mathrm{AI}$, the farmland decreased obviously, forestland and grassland remained stable, and the water first decreased and then increased. The changes of these indicators all show that patches of farmland are constantly being cut, their shapes tend to be complex, and their fragmentation is intensified to some extent. A decade ago, due to population reproduction 
and afforestation projects, forestland was gradually distributed contiguously. However, in the last decade, this weakened somewhat, falling back to a situation similar to that of 2000, and the fragmentation degree is now relatively stable. It can be seen that the impact of urban agglomeration expansion on forestland is limited, which may be due to the following reasons: Firstly, most of the forestland is distributed in mountainous areas, and because of the influence of terrain, the cost is relatively high, and it is unlikely to face interference and be changed by humans; secondly, at the beginning of the 21st century, serious forestland degradation caused Beijing to be frequently attacked by natural disasters such as sandstorms, which enhanced the government's awareness of forest management and ecological barrier construction. In addition, urban events such as the 2008 Olympic Games caused the government and citizens to pay attention to environmental quality, which made afforestation and forestland protection an important task. In the first decade, the area of grassland increased and patches tended to be complete, but in the last decade, due to the acceleration of urban expansion, the grassland was damaged and the degree of fragmentation was intensified. During the research period, water was also found to be damaged and fragmented, which may have been caused by the impact of urban expansion or severe exploitation, and the implementation of the "water to drought" project in some regional water systems such as the Chaobai River Basin in 2006.
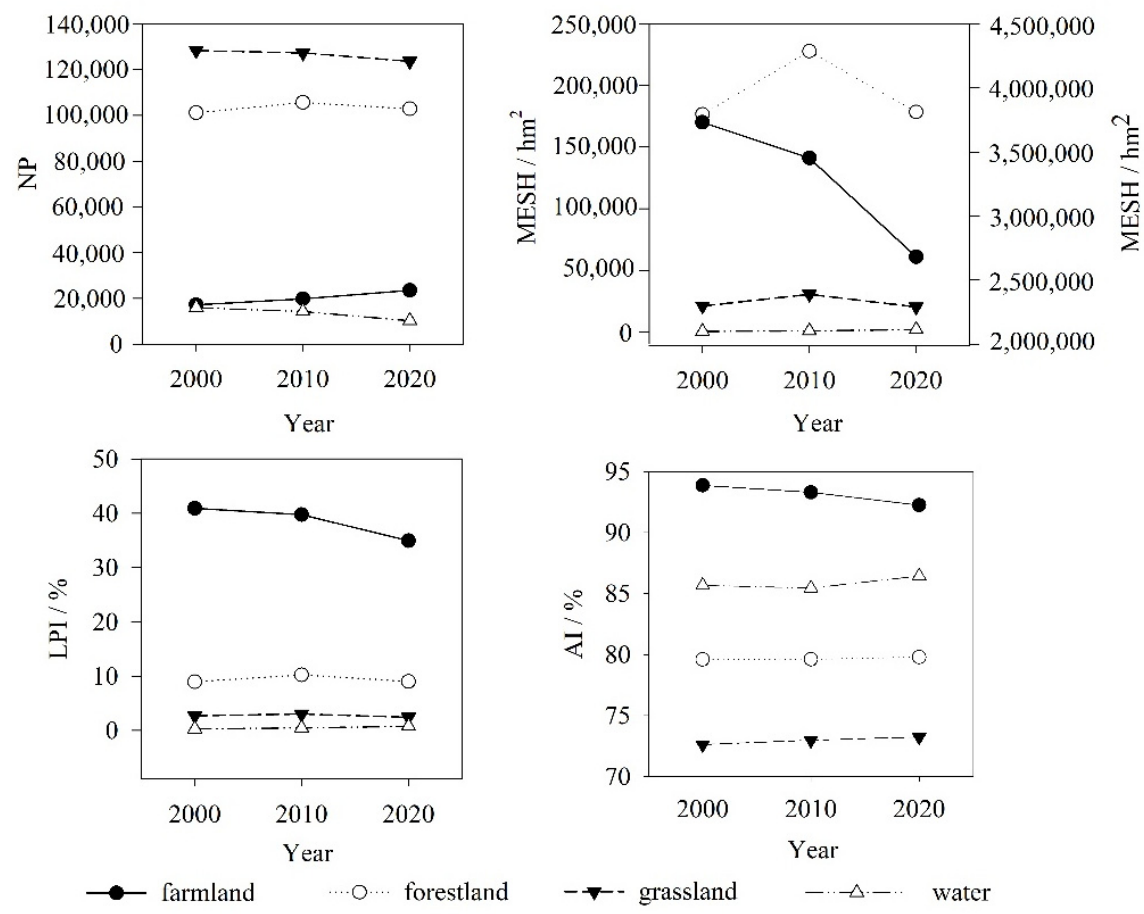

Figure 6. Changes in landscape metrics in the study area in class level.

\subsection{Correlation Analysis and Simulation Prediction between Urban Expansion and Green Space Fragmentation}

3.3.1. Correlation Analysis between Urban Expansion and Green Space Fragmentation

The correlation of urban expansion and green space fragmentation is characterized by the Pearson correlation coefficient. As shown in Table 5, the proportion, fragmentation, and expansion intensity of built-up areas are negatively correlated with the fragmentation of farmland, indicating that quantity expansion, expansion intensity, change rate, and fragmentation pattern of built-up areas in the BTH urban agglomeration are closely related to the fragmentation of farmland, and the expansion of built-up areas obviously leads to the increase in fragmentation of farmland. Besides, there is a positive correlation between forestland fragmentation and the proportion and fragmentation of built-up areas; and forestland fragmentation is significantly and positively correlated with the expansion 
intensity of built-up areas, which shows that though forestland has been protected to some extent in the process of urban expansion, there is still a certain degree of correlation between urban expansion and forestland pattern. As for grassland, its fragmentation is negatively correlated with the proportion and fragmentation of built-up areas and positively correlated with the expansion intensity of built-up areas, indicating that urban expansion is related to the change in grassland fragmentation and supporting the above conclusion that the impact of urban expansion on grassland is mostly about built-up areas swallowing small grassland patches. As for metrics of water, it is negatively correlated with the proportion and fragmentation of built-up areas, and significantly and negatively correlated with the expansion intensity of built-up areas, indicating that urban expansion is related to the water pattern to a certain extent. In summary, the changing intensity of fragmentation of farmland, forestland, grassland, and water is negatively correlated with the proportion, fragmentation, and expansion intensity of built-up areas at 0.01 level, which shows that urban expansion is a significant correlation factor of green space fragmentation.

Table 5. Correlation coefficient between urban expansion and green space fragmentation from 2000 to 2020 .

\begin{tabular}{cccc}
\hline & B-PLAND & B-MESH & B-P \\
\hline F1-MESH & $-1.000^{* *}$ & $-1.000^{*}$ & $-1.000^{* *}$ \\
F2-MESH & 0.827 & 0.844 & $1.000^{* *}$ \\
G-MESH & -0.339 & -0.309 & $1.000^{* *}$ \\
W-MESH & -0.176 & -0.208 & $-1.000^{* *}$ \\
F1-FG & $-1.000^{* *}$ & $-1.000^{* *}$ & $-1.000^{* *}$ \\
F2-FG & $-1.000^{* *}$ & $-1.000^{* *}$ & $-1.000^{* *}$ \\
G-FG & $-1.000^{* *}$ & $-1.000^{* *}$ & $-1.000^{* *}$ \\
W-FG & $-1.000^{* *}$ & $-1.000^{* *}$ & $-1.000^{* *}$ \\
\hline
\end{tabular}

* means significant correlation at 0.05 level; ${ }^{* *}$ means significant correlation at 0.01 level.

\subsubsection{Forecast of Land Use in 2030 Based on FLUS Model}

Based on land use data of BTH in 2010, we chose elevation, slope, aspect, distance to the municipal government, distance to the town government, distance to the highway, distance to the railway, and population as driving factors to calculate suitability probability. Based on the model tests and expert knowledge, after a series of debugging and verification tests, the simulation parameters are determined, and the simulation accuracy is verified by using the overall accuracy (OA) and Kappa coefficient. Among them, the OA value and Kappa coefficient are between 0 and 1, and the closer to 1, the higher the simulation accuracy. The Kappa coefficient of this paper is 0.7264 and the overall accuracy is $81.30 \%$, which shows that the simulation effect is remarkable and suitable for predicting future land use change in the BTH region.

As can be seen in Figure 7, built-up areas continuously encroach on farmland, forestland, grassland, and other types of land around towns, but the encroachment on farmland is relatively slow and that on grassland is intensified. Generally, there are two major characteristics: The "extended" expansion centered on Beijing is remarkable, and the fragmentation of green space in Beijing urban area is intensified; the band expansion mode along the traffic trunk line is more prominent and the built-up areas are concentrated along the development axis of "Beijing-Baoding-Shijiazhuang", but it is relatively less driven to other regions. The built-up areas in Beijing, Tianjin, and Hebei have expanded significantly, and the fragmentation of farmland has obviously intensified.

In terms of fragmentation of green space, it can be seen from Table 6 that compared with 2020, the AI of farmland will decrease in 2030, and so its agglomeration will be further weakened. While the area is further reduced, its NP increases and MESH and LPI decrease, indicating that its large patches may continue to separate into small patches and landscape fragmentation would be further aggravated. The size of grassland and water also decrease slightly, and NP increases while AI decreases, so their fragmentation may be increased. 
However, as for forestland, its NP decreases while the MESH, AI and LPI increase, so its landscape may connect with each other and fragmentation may decrease. Overall, in 2030, the scale of green space in BTH urban agglomeration will be further reduced, and the fragmentation of farmland, grassland, and water will be further aggravated. Although the scale of forestland will be reduced slightly, its fragmentation will still be lower.

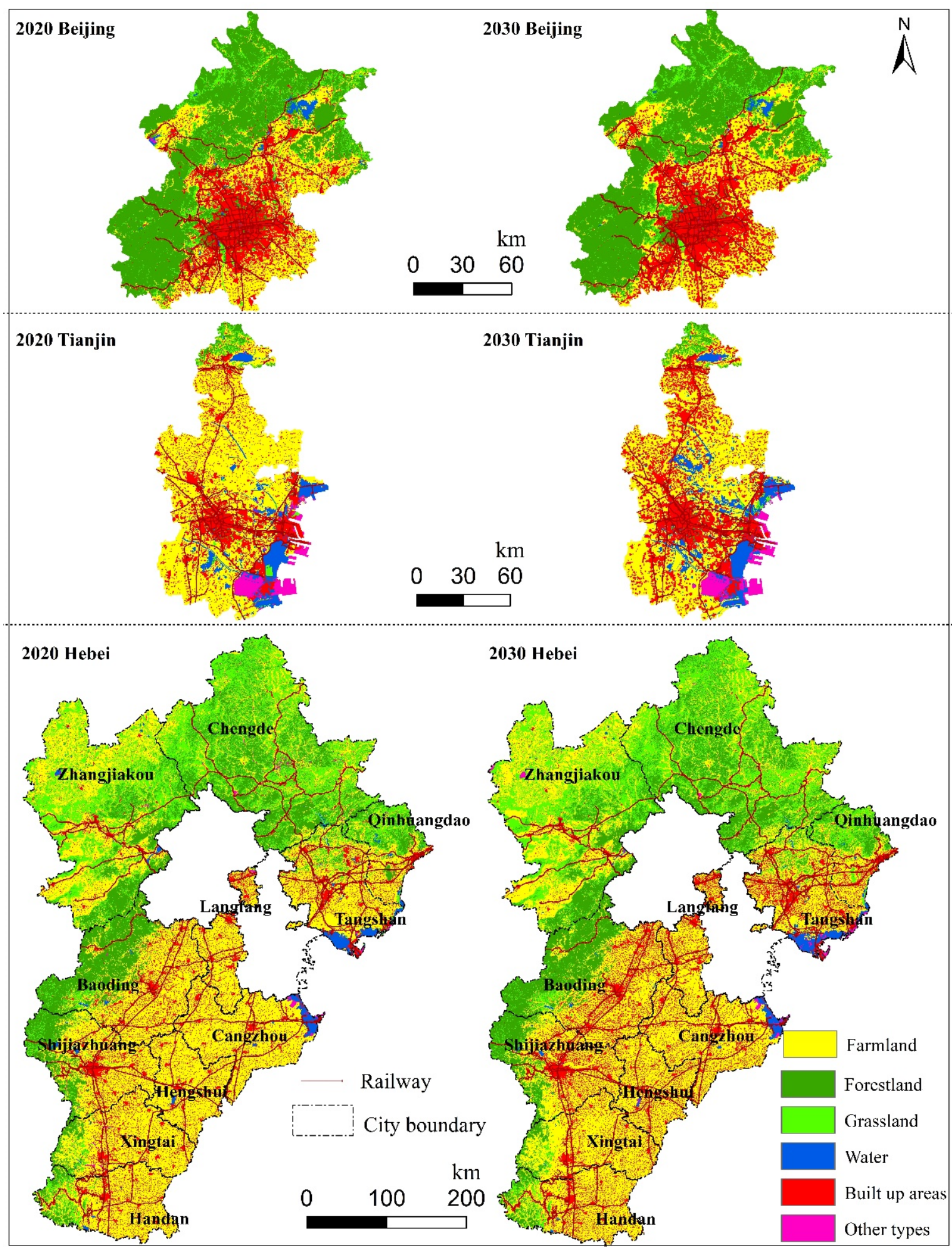

Figure 7. Land use forecast map of BTH region in 2030. 
Table 6. Area and landscape metrics of the study area in 2020 and 2030 in class level.

\begin{tabular}{ccccccc}
\hline & Year & Area/km & NP & MESH/hm & AI/\% & LPI/\% \\
\hline \multirow{2}{*}{ Farmland } & 2020 & $104,307.47$ & 23,585 & $2,681,091$ & 92.24 & 34.94 \\
\cline { 2 - 6 } & 2030 & $98,170.91$ & 31,555 & $2,210,118$ & 90.71 & 31.70 \\
\hline \multirow{2}{*}{ Forestland } & 2020 & $42,123.39$ & 102,913 & 178,350 & 79.78 & 8.99 \\
\cline { 2 - 6 } & 2030 & $41,753.53$ & 98,158 & 237,462 & 79.98 & 10.44 \\
\hline \multirow{2}{*}{ Grassland } & 2020 & $38,246.02$ & 123,756 & 20,167 & 73.24 & 2.39 \\
\cline { 2 - 6 } & 2030 & $38,003.35$ & 127,926 & 23,261 & 72.90 & 2.66 \\
\hline \multirow{2}{*}{ Built up areas } & 2020 & $26,529.37$ & 49,088 & 1868 & 83.17 & 0.76 \\
\cline { 2 - 6 } & 2030 & $33,218.07$ & 27,009 & 15,922 & 84.90 & 2.32 \\
\hline \multirow{2}{*}{ Water } & 2020 & 3907.96 & 10,288 & 423 & 86.43 & 0.29 \\
\cline { 2 - 6 } & 2030 & 3899.30 & 14,301 & 608 & 85.42 & 0.47 \\
\hline
\end{tabular}

The above results show that the expansion of BTH urban agglomeration encroaches on green space. Among them, implementation of farmland protection measures in China may be one of the reasons for the slowdown in occupation of cultivated land. However, at the same time, there are still some issues such as different local policies in land management operation and slow policy advancement [82] that may lead to the protection of farmland in some areas at the expense of ecological land [83]. In short, some studies have shown that green space has improved the quality of urban life in various aspects, such as providing ecosystem services, protecting biodiversity, reducing the urban heat island effect, and improving the health and well-being of urban residents [84-86]. Therefore, fragmentation of green space not only reduces habitat area but also breaks the landscape pattern of the ecosystem, harming the maintenance of biodiversity and ecological balance. How to balance the supply and demand of green space and ensure the sustainable development of the city is the focus of future regional planning.

\section{Discussion}

BTH urban agglomeration is an important carrier of China's economic, technological, and cultural development, and has a strong siphon effect. However, it also has a radiation effect that strongly drives change of land use within its jurisdiction and drastically alters the regional landscape pattern, leading to particularly prominent ecological pressure. This study is of great significance for understanding the impact of urban expansion on landscape patterns and coordinating the relationship between urban agglomeration expansion and the ecological environment.

At present, most research on urban expansion focuses on the representation of its spatial characteristics [87]; for example, Zhang studied the characteristics of urban expansion in Beijing, Tianjin, and Shijiazhuang over the last 30 years [88]. Besides, a few scholars are concerned about the impact of urban expansion on farmland [89]. However, there is a lack of research on the correlation between urban expansion and green land fragmentation [70-72]. This paper links the two, filling the gap and proving to be of strong practical significance. Secondly, existing research based on the green space in the BTH region is mostly confined to the interiors of Beijing urban area [90]. There may be great differences in landscape changes at the scale of urban agglomeration, and so our results help complete the research on green space patterns and the sustainable development of urban agglomeration. In addition, most related studies only focus on the empirical study of the past or present urban expansion while ignoring the future situation. This paper creatively used the FLUS model to predict the future land use situation, so it can more intuitively address the problems that we may face under the influence of existing policies and related factors; it may play a guiding role in timely adjustment of relevant policies. 
However, due to the fuzziness of the concept and the subjectivity of index selection, there are some limitations to this paper. Moreover, urban expansion and landscape pattern replacement are complex dynamic processes. To have a more comprehensive and in-depth understanding, we suggest that future research apply data with a higher spatial-temporal resolution that enables more detailed examination.

\section{Conclusions}

In this paper, we took BTH urban agglomeration as the research area and combined landscape pattern index, FLUS model, and other methods to explore the influence of urban agglomeration expansion on the fragmentation of green space. The main conclusions are as follows:

(1) From 2000 to 2020, the expansion of BTH urban agglomeration generally accelerated mainly in the eastern and southern plain areas, and the spreading trend has intensified over time. It presents the expansion mode that the central city leads the development of urban agglomeration and urban agglomeration drives regional development.

(2) In the past 20 years, the overall area of green space in BTH urban agglomeration has decreased, fragmentation at the landscape level has increased, and the degree of landscape segmentation has intensified. Among them, farmland was continuously destroyed, becoming the most affected by urban expansion. There was less fragmentation of grassland and water, and the fragmentation of forestland was relatively stable.

(3) There is a significant correlation between urban expansion and green space fragmentation. As a result of urban expansion, ecological resources such as farmland, forests, and grass gradually disappear, having a negative impact on the ecological environment. By 2030, built-up areas may continue to occupy other land types around cities and towns along the main traffic lines and development axis, intensifying the fragmentation of farmland, grassland, and water, but the impact on forestland is inapparent.

Future development planning of the BTH region should continue to strengthen the protection of farmland and ecological land, make rational use of sloping land, and reduce the encroachment on cultivated land [91]. The boundary of urban development should be strictly controlled. The underground and aboveground space should be rationally and comprehensively developed to improve the efficiency of urban land use. The regional development layout should be optimized to promote coordinated development of the overall economy and ecological protection in the BTH urban agglomeration.

Author Contributions: Conceptualization, D.S.; methodology, M.C. and D.S.; formal analysis, M.C.; investigation, M.C.; resources, D.S.; writing-original draft preparation, M.C. and J.L.; writingreview and editing, M.C., J.L. and D.S.; supervision, D.S. All authors have read and agreed to the published version of the manuscript.

Funding: This research was funded by the National Natural Science Foundation of China (Grant nos. 41971162).

Institutional Review Board Statement: Not applicable.

Informed Consent Statement: Not applicable.

Data Availability Statement: Land cover data were collected from the National Geomatics Center of China: http://www.globallandcover.com/. DEM data were collected from the Shuttle radar topography mission data set. Road network data were collected from the OpenStreetMap website: https: / / planet.openstreetmap.org/. Administrative division data and coordinate data of the town government were collected from the National Catalogue Service For Geographic Information: https: / / www.webmap.cn.

Conflicts of Interest: The authors declare no conflict of interest. 


\section{References}

1. UN-Habitat. United Nations Human Settlements Programme World Cities Report 2020: The Value of Sustainable Urbanization; UNHabitat: Nairobi, Kenya, 2020. [CrossRef]

2. Xu, X.; Min, X. Quantifying spatiotemporal patterns of urban expansion in China using remote sensing data. Cities 2013, 35, 104-113. [CrossRef]

3. Seto, K.C.; Sánchez-Rodríguez, R.; Fragkias, M. The New Geography of Contemporary Urbanization and the Environment. Annu. Rev. Environ. Resour. 2010, 35, 167-194. [CrossRef]

4. Wu, J.; He, C.; Huang, G.; Yu, D. Urban landscape ecology: Past, present, and future. In Landscape Ecology for Sustainable Environment and Culture; Fu, B., Jones, K.B., Eds.; Springer: Dordrecht, The Netherlands, 2013; pp. 37-53. [CrossRef]

5. Cheng, J.; Masser, I. Urban growth pattern modeling: A case study of Wuhan city, PR China. Landsc. Urban Plan. 2003, 62, 199-217. [CrossRef]

6. Luo, J.; Wei, Y.D. Modeling spatial variations of urban growth patterns in Chinese cities: The case of Nanjing. Landsc. Urban Plan. 2009, 91, 51-64. [CrossRef]

7. Deng, X.; Huang, J.; Rozelle, S.; Uchida, E. Growth, population and industrialization, and urban land expansion of China. J. Urban Econ. 2008, 63, 96-115. [CrossRef]

8. Deng, X.; Huang, J.; Rozelle, S.; Uchida, E. Economic Growth and the Expansion of Urban Land in China. Urban Stud. 2009, 47, 813-843. [CrossRef]

9. Liu, Y.; Li, Y. Revitalize the world's countryside. Nature 2017, 548, 275-277. [CrossRef]

10. Li, W.; Li, X.; Tan, M.; Wang, Y. Influences of population pressure change on vegetation greenness in China's mountainous areas. Ecol. Evol. 2017, 7, 9041-9053. [CrossRef]

11. Schneider, A.; Woodcock, C.E. Compact, Dispersed, Fragmented, Extensive? A Comparison of Urban Growth in Twenty-five Global Cities using Remotely Sensed Data, Pattern Metrics and Census Information. Urban Stud. 2008, 45, 659-692. [CrossRef]

12. Tayyebi, A.; Perry, P.C.; Tayyebi, A.H. Predicting the expansion of an urban boundary using spatial logistic regression and hybrid raster-vector routines with remote sensing and GIS. Int. J. Geogr. Inf. Sci. 2014, 28, 639-659. [CrossRef]

13. Frumkin, H. Urban sprawl and public health. Public Health Rep. 2002, 117, 201-217. [CrossRef]

14. Nuissl, H.; Haase, D.; Lanzendorf, M.; Wittmer, H. Environmental impact assessment of urban land use transitions-A contextsensitive approach. Land Use Policy 2009, 26, 414-424. [CrossRef]

15. Artmann, M.; Kohler, M.; Meinel, G.; Gan, J.; Ioja, I.-C. How smart growth and green infrastructure can mutually support each other-A conceptual framework for compact and green cities. Ecol. Indic. 2019, 96, 10-22. [CrossRef]

16. National Research Council. Grand Challenges in Environmental Sciences; National Academies Press: Washington, DC, USA, 2001. [CrossRef]

17. Jaeger, J.A.G.; Bertiller, R.; Schwick, C.; Müller, K.; Steinmeier, C.; Ewald, K.C.; Ghazoul, J. Implementing Landscape Fragmentation as an Indicator in the Swiss Monitoring System of Sustainable Development (Monet). J. Environ. Manag. 2008, 88, 737-751. [CrossRef] [PubMed]

18. Breuste, J.; Feldmann, H.; Uhlmann, O. Urban Ecology; Springer: Berlin, Germany, 1998. [CrossRef]

19. Kim, K.-H.; Pauleit, S. Landscape character, biodiversity and land use planning: The case of Kwangju City Region, South Korea. Land Use Policy 2007, 24, 264-274. [CrossRef]

20. Zhou, L.; Zhou, C.; Che, L.; Wang, B. Spatio-temporal evolution and influencing factors of urban green development efficiency in China. J. Geogr. Sci. 2020, 30, 724-742. [CrossRef]

21. Bryan, B.A.; Gao, L.; Ye, Y.; Sun, X.; Connor, J.D.; Crossman, N.D.; Stafford-Smith, M.; Wu, J.; He, C.; Yu, D.; et al. China's response to a national land-system sustainability emergency. Nature 2018, 559, 193-204. [CrossRef]

22. Waddell, P. UrbanSim: Modeling Urban Development for Land Use, Transportation, and Environmental Planning. J. Am. Plan. Assoc. 2002, 68, 297-314. [CrossRef]

23. Gordon, P.; Richardson, H.W. Are Compact Cities a Desirable Planning Goal? J. Am. Plan. Assoc. 1997, 63, 95-106. [CrossRef]

24. Dennis, C.; Marsland, D.; Cockett, T. Central place practice: Shopping centre attractiveness measures, hinterland boundaries and the UK retail hierarchy. J. Retail. Consum. Serv. 2002, 9, 185-199. [CrossRef]

25. Forman, R.T.T. Land Mosaics: The Ecology of Landscapes and Regions. In The Ecological Design and Planning Reader; Island Press: Washington, DC, USA, 1995.

26. Wilson, E.H.; Hurd, J.D.; Civco, D.L.; Prisloe, M.P.; Arnold, C. Development of a geospatial model to quantify, describe and map urban growth. Remote Sens. Environ. 2003, 86, 275-285. [CrossRef]

27. Xu, C.; Liu, M.; Zhang, C.; An, S.; Yu, W.; Chen, J.M. The spatiotemporal dynamics of rapid urban growth in the Nanjing metropolitan region of China. Landsc. Ecol. 2007, 22, 925-937. [CrossRef]

28. Pham, H.M.; Yamaguchi, Y. Urban growth and change analysis using remote sensing and spatial metrics from 1975 to 2003 for Hanoi, Vietnam. Int. J. Remote Sens. 2011, 32, 1901-1915. [CrossRef]

29. Herold, M.; Goldstein, N.C.; Clarke, K.C. The spatiotemporal form of urban growth: Measurement, analysis and modeling. Remote Sens. Environ. 2003, 86, 286-302. [CrossRef]

30. Tian, G.; Qiao, Z.; Zhang, Y. The investigation of relationship between rural settlement density, size, spatial distribution and its geophysical parameters of China using Landsat TM images. Ecol. Model. 2012, 231, 25-36. [CrossRef]

31. Poelmans, L.; Van Rompaey, A. Detecting and modelling spatial patterns of urban sprawl in highly fragmented areas: A case study in the Flanders-Brussels region. Landsc. Urban Plan. 2009, 93, 10-19. [CrossRef]

32. Stern, P.C.; Druckman, D.; Young, O.R. Global Environmental Change Understanding the Human Dimensions; National Academy Press: Washington, DC, USA, 1992. [CrossRef] 
33. Allan, T.; Meyer, W.B.; Turner, B. Changes in Land Use and Land Cover: A Global Perspective. Geogr. J. 1996, 162, 107. [CrossRef]

34. You, H.; Yang, X. Urban expansion in 30 megacities of China: Categorizing the driving force profiles to inform the urbanization policy. Land Use Policy 2017, 68, 531-551. [CrossRef]

35. Magliocca, N.; McConnell, V.; Walls, M. Exploring sprawl: Results from an economic agent-based model of land and housing markets. Ecol. Econ. 2015, 113, 114-125. [CrossRef]

36. Colantoni, A.; Grigoriadis, E.; Sateriano, A.; Venanzoni, G.; Salvati, L. Cities as selective land predators? A lesson on urban growth, deregulated planning and sprawl containment. Sci. Total Environ. 2016, 545-546, 329-339. [CrossRef]

37. Tong, L.; Hu, S.; Frazier, A.E.; Liu, Y. Multi-order urban development model and sprawl patterns: An analysis in China, 2000-2010. Landsc. Urban Plan. 2017, 167, 386-398. [CrossRef]

38. Long, Y. Redefining Chinese city system with emerging new data. Appl. Geogr. 2016, 75, 36-48. [CrossRef]

39. Patino, J.E.; Duque, J.C. A review of regional science applications of satellite remote sensing in urban settings. Comput. Environ. Urban Syst. 2013, 37, 1-17. [CrossRef]

40. Handayani, H.H.; Murayama, Y.; Ranagalage, M.; Liu, F.; Dissanayake, D. Geospatial Analysis of Horizontal and Vertical Urban Expansion Using Multi-Spatial Resolution Data: A Case Study of Surabaya, Indonesia. Remote Sens. 2018, 10, 1599. [CrossRef]

41. White, R.; Engelen, G. Cellular Automata and Fractal Urban Form: A Cellular Modelling Approach to the Evolution of Urban Land-Use Patterns. Environ. Plan. A Econ. Space 1993, 25, 1175-1199. [CrossRef]

42. Liu, X.; Liang, X.; Li, X.; Xu, X.; Ou, J.; Chen, Y.; Li, S.; Wang, S.; Pei, F. A future land use simulation model (FLUS) for simulating multiple land use scenarios by coupling human and natural effects. Landsc. Urban Plan. 2017, 168, 94-116. [CrossRef]

43. Tian, G.; Ouyang, Y.; Quan, Q.; Wu, J. Simulating spatiotemporal dynamics of urbanization with multi-agent systems-A case study of the Phoenix metropolitan region, USA. Ecol. Model. 2011, 222, 1129-1138. [CrossRef]

44. Clarke, K.C.; Hoppen, S.; Gaydos, L. A self-modifying cellular automaton model of historical urbanization in the San Francisco Bay area. Environ. Plan. B Plan. Des. 1997, 24, 247-261. [CrossRef]

45. Li, X.; Yeh, A.G.-O. Neural-network-based cellular automata for simulating multiple land use changes using GIS. Int. J. Geogr. Inf. Sci. 2002, 16, 323-343. [CrossRef]

46. Zhou, L.; Dang, X.; Sun, Q.; Wang, S. Multi-scenario simulation of urban land change in Shanghai by random forest and CA-Markov model. Sustain. Cities Soc. 2020, 55, 102045. [CrossRef]

47. Ngom, R.; Gosselin, P.; Blais, C. Reduction of disparities in access to green spaces: Their geographic insertion and recreational functions matter. Appl. Geogr. 2016, 66, 35-51. [CrossRef]

48. Yang, J.; Li, C.; Li, Y.; Xi, J.; Ge, Q.; Li, X. Urban green space, uneven development and accessibility: A case of Dalian's Xigang District. Chin. Geogr. Sci. 2015, 25, 644-656. [CrossRef]

49. Morris, K.I.; Chan, A.; Ooi, M.; Oozeer, Y.; Abakr, Y.A.; Morris, K.J.K. Effect of vegetation and waterbody on the garden city concept: An evaluation study using a newly developed city, Putrajaya, Malaysia. Comput. Environ. Urban Syst. 2016, 58, 39-51. [CrossRef]

50. Gong, J.; Liu, Y.; Xia, B. Spatial heterogeneity of urban land-cover landscape in Guangzhou from 1990 to 2005. J. Geogr. Sci. 2009, 19, 213-224. [CrossRef]

51. Liu, Y.; Huang, X.; Yang, H.; Zhong, T. Environmental effects of land-use/cover change caused by urbanization and policies in Southwest China Karst area-A case study of Guiyang. Habitat Int. 2014, 44, 339-348. [CrossRef]

52. Butlin, F.M.; Howard, E. To-morrow: A Peaceful Path to Real Reform. Econ. J. 1898, 9, 71. [CrossRef]

53. Turner, T. Open space planning in London: From standards per 1000 to green strategy. Town Plan. Rev. 1992, 63, 365-386. [CrossRef]

54. Dai, D. Racial/ethnic and socioeconomic disparities in urban green space accessibility: Where to intervene? Landsc. Urban Plan. 2011, 102, 234-244. [CrossRef]

55. Haq, S.M.A. Urban Green Spaces and an Integrative Approach to Sustainable Environment. J. Environ. Prot. 2011, 2, 601-608. [CrossRef]

56. Kabisch, N.; Haase, D. Green spaces of European cities revisited for 1990-2006. Landsc. Urban Plan. 2013, 110, 113-122. [CrossRef]

57. Sandstro“m, U.G. Green Infrastructure Planning in Urban Sweden. Plan. Pract. Res. 2002, 17, 373-385. [CrossRef]

58. Tzoulas, K.; Korpela, K.; Venn, S.; Yli-Pelkonen, V.; Kaźmierczak, A.; Niemela, J.; James, P. Promoting ecosystem and human health in urban areas using Green Infrastructure: A literature review. Landsc. Urban Plan. 2007, 81, 167-178. [CrossRef]

59. Taylor, L.; Hochuli, D.F. Defining greenspace: Multiple uses across multiple disciplines. Landsc. Urban Plan. 2017, 158, 25-38. [CrossRef]

60. Li, F.; Wang, R.; Paulussen, J.; Liu, X. Comprehensive concept planning of urban greening based on ecological principles: A case study in Beijing, China. Landsc. Urban Plan. 2005, 72, 325-336. [CrossRef]

61. Zhou, X.; Wang, Y.-C. Spatial-temporal dynamics of urban green space in response to rapid urbanization and greening policies. Landsc. Urban Plan. 2011, 100, 268-277. [CrossRef]

62. Botequilha-Leitao, A.; Ahern, J. Applying landscape ecological concepts and metrics in sustainable landscape planning. Landsc. Urban Plan. 2002, 59, 65-93. [CrossRef]

63. Hamada, S.; Ohta, T. Seasonal variations in the cooling effect of urban green areas on surrounding urban areas. Urban For. Urban Green. 2010, 9, 15-24. [CrossRef]

64. Beckett, K.P.; Freer-Smith, P.H.; Taylor, G. The capture of particulate pollution by trees at five contrasting urban sites. Arboric. J. 2000, 24, 209-230. [CrossRef]

65. Kabisch, N.; Qureshi, S.; Haase, D. Human-environment interactions in urban green spaces-A systematic review of contemporary issues and prospects for future research. Environ. Impact Assess. Rev. 2015, 50, 25-34. [CrossRef]

66. Cooper, D.S. Geographic associations of breeding bird distribution in an urban open space. Biol. Conserv. 2002, 104, 205-210. [CrossRef] 
67. Haire, S.; Bock, C.; Cade, B.; Bennett, B. The role of landscape and habitat characteristics in limiting abundance of grassland nesting songbirds in an urban open space. Landsc. Urban Plan. 2000, 48, 65-82. [CrossRef]

68. Rubino, M.J.; Hess, G.R. Planning open spaces for wildlife 2: Modeling and verifying focal species habitat. Landsc. Urban Plan. 2003, 64, 89-104. [CrossRef]

69. Tian, Y.; Jim, C.; Tao, Y.; Shi, T. Landscape ecological assessment of green space fragmentation in Hong Kong. Urban For. Urban Green. 2011, 10, 79-86. [CrossRef]

70. Wu, Q.; Hu, D.; Wang, R.; Li, H.; He, Y.; Wang, M.; Wang, B. A GIS-based moving window analysis of landscape pattern in the Beijing metropolitan area, China. Int. J. Sustain. Dev. World Ecol. 2006, 13, 419-434. [CrossRef]

71. Qian, Y.; Zhou, W.; Li, W.; Han, L. Understanding the dynamic of greenspace in the urbanized area of Beijing based on high resolution satellite images. Urban For. Urban Green. 2015, 14, 39-47. [CrossRef]

72. Yu, X.J.; Ng, C.N. Spatial and temporal dynamics of urban sprawl along two urban-rural transects: A case study of Guangzhou, China. Landsc. Urban Plan. 2007, 79, 96-109. [CrossRef]

73. Liu, Y.; Song, W.; Deng, X. Understanding the spatiotemporal variation of urban land expansion in oasis cities by integrating remote sensing and multi-dimensional DPSIR-based indicators. Ecol. Indic. 2018, 96, 23-37. [CrossRef]

74. Liu, W.; Zhan, J.; Zhao, F.; Yan, H.; Zhang, F.; Wei, X. Impacts of urbanization-induced land-use changes on ecosystem services: A case study of the Pearl River Delta Metropolitan Region, China. Ecol. Indic. 2018, 98, 228-238. [CrossRef]

75. McGarigal, K.; Marks, B.J. FRAGSTATS: Spatial pattern analysis program for quantifying landscape structure. In General Technical Report; PNW-GTR-351; US Department of Agriculture, Forest Service, Pacific Northwest Research Station: Portland, OR, USA, 1995; pp. 1-122.

76. Weng, Y.-C. Spatiotemporal changes of landscape pattern in response to urbanization. Landsc. Urban Plan. 2007, 81, 341-353. [CrossRef]

77. McDonald, R.I.; Urban, D.L. Spatially varying rules of landscape change: Lessons from a case study. Landsc. Urban Plan. 2006, 74, 7-20. [CrossRef]

78. Peng, J.; Wang, Y.; Zhang, Y.; Wu, J.; Li, W.; Li, Y. Evaluating the effectiveness of landscape metrics in quantifying spatial patterns. Ecol. Indic. 2010, 10, 217-223. [CrossRef]

79. Jiao, L.M.; Xiao, F.T.; Xu, G. Spatial-temporal response of green land fragmentation patterns to urban expansion in Wuhan metropolitan area. Resour. Sci. 2015, 37, 1650-1660. (In Chinese)

80. Wu, Z.F.; Li, D.Q.; Hu, Y.H. A quantitative analysis on the fragmentation of cultivated land on the two sides of the zhujiang estrary. Trop. Geogr. 2005, 25, 107-110. (In Chinese)

81. Guneroglu, N.; Acar, C.; Dihkan, M.; Karsli, F.; Guneroglu, A. Green corridors and fragmentation in South Eastern Black Sea coastal landscape. Ocean Coast. Manag. 2013, 83, 67-74. [CrossRef]

82. Liu, Y.; Wang, G.H. The Current Situation, Problems and Innovation Mechanism of Land Management Integration in Beijing, Tianjin and Hebei. Reform Econ. Syst. 2020, 5, 80-85. (In Chinese)

83. Zhu, G.F. The Research on Cultivated Land Transitions from the Perspective of Cultivated Land Protection. Master's Thesis, Wuhan University, Wuhan, China, 2019. (In Chinese).

84. Mehrotra, S.; Bardhan, R.; Ramamritham, K. Outdoor thermal performance of heterogeneous urban environment: An indicatorbased approach for climate-sensitive planning. Sci. Total Environ. 2019, 669, 872-886. [CrossRef]

85. Xu, X.G.; Cui, C.W.; Xu, L.F.; Ma, L.Y. Method study on relative assessment for ecosystem service: A case of green space in Beijing, China. Environ. Earth Sci. 2012, 68, 1913-1924. [CrossRef]

86. Li, B.J.; Chen, D.X.; Wu, S.H. Spatio-temporal assessment of urbanization impacts on ecosystem services: Case study of Nanjing City, China. Ecol. Indic. 2016, 71, 416-427. [CrossRef]

87. Zhang, X.; Pan, J. Spatiotemporal Pattern and Driving Factors of Urban Sprawl in China. Land 2021, 10, 1275. [CrossRef]

88. Zhang, Z.; Li, N.; Wang, X. A Comparative Study of Urban Expansion in Beijing, Tianjin and Tangshan from the 1970 s to 2013. Remote Sens. 2016, 8, 496. [CrossRef]

89. Tan, M.; Li, X.; Xie, H.; Lu, C. Urban land expansion and arable land loss in China-a case study of Beijing-Tianjin-Hebei region. Land Use Policy 2005, 22, 187-196. [CrossRef]

90. Fu, G.; Xiao, N.; Qiao, M.; Qin, Y.; Yan, B.; Liu, G.; Gao, X.; Li, J. Spatial-temporal changes of landscape fragmentation patterns in Beijing in the last two decades. Acta Ecol. Sin. 2017, 37, 2551-2562. (In Chinese)

91. Zhou, L.; Dang, X.; Mu, H.; Wang, B.; Wang, S. Cities are going uphill: Slope gradient analysis of urban expansion and its driving factors in China. Sci. Total Environ. 2021, 775, 145836. [CrossRef] [PubMed] 